\title{
TRADUCIR LA METAPOÉTICA EN EIKÓNES DE LUCIANO: DE LAS VERSIONES ESPAÑOLAS DE "LOS RETRATOS" HASTA UNA VERSIÓN ARGENTINA DE "IMÁGENES"
}

\section{TRANSLATING THE METAPOETIC IN EIKÓNES BY LUCIAN: FROM THE SPANISH VERSIONS OF "THE PORTRAITS" TO AN ARGENTINE VERSION OF "IMAGES" 1}

\author{
Gabriela Baralle* \\ Ivana Chialva**
}

\section{RESUMEN}

A partir del presupuesto de que toda traducción constituye una reescritura que fija una lectura y otorga una posición en la cultura de llegada, nos preguntamos por las condiciones de producción y circulación de dos de las traducciones vigentes del opúsculo Imágenes (Eikónes) de Luciano de Samosata, texto escrito hacia el siglo II d.C. en un griego ático artificioso, propio del movimiento aticista de la Segunda Sofística. De este modo, mediante la articulación de la perspectiva filológica, la traductología de Antoine Berman y los Estudios Descriptivos de la Traducción, nos proponemos observar críticamente el modo en que ha sido interpretado. En este trabajo presentamos la lectura y cotejo de un pasaje en el que se evidencian múltiples decisiones de traducción que dan cuenta de distintas concepciones de la escritura luciánica y de la tarea de traducir. Se observa allí que las operaciones de traducción analizadas soslayan la dimensión satírica y metapoética del texto y privilegian una lectura encomiástica. Los avances aquí presentados forman parte de la etapa inicial de la producción de una versión propia en la que buscamos recuperar aquellas marcas que han sido matizadas en las traducciones al español peninsular. En este sentido, el proyecto se enmarca en una indagación más amplia de los procesos de importación de los textos clásicos entre España y Argentina y cómo estos delimitan y resguardan sus posibles modos de lectura y enseñanza.

\footnotetext{
* Universidad Nacional del Litoral, Santa Fé, Argentina. gabi.baralle@live.com.ar
}

** Universidad Nacional del Litoral, Santa Fé, Argentina. ichialva@gmail.com

1. El presente trabajo forma parte de un proyecto presentado en el marco de una Beca de Iniciación a la Investigación ("Cientibeca") -financiada por la Universidad Nacional del Litoral- titulado "El problema del lógos luciánico en Imágenes (Eikónes): problemáticas de traducción de un texto polifónico", dirigido por la Dra. Ivana Chialva (CONICET-UNL) y el Dr. Santiago Venturini (CONICETUNL). La investigación busca interrogar las problemáticas específicas de traducción de la escritura luciánica a partir del análisis de las traducciones disponibles en tensión con la producción de una propia versión. Esta beca se integra en el proyecto CAI+D (2011) Transformaciones del lógos en la primera y segunda sofísticas: de la Grecia clásica al Imperio romano, dirigido por la Dra. Ivana Chialva. 
Palabras clave: Eikónes; traductología; Segunda Sofística; Luciano de Samosata; écfrasis; metapoética.

\section{ABSTRACT}

From the assumption that every translation is a rewriting that fixes an interpretation and gives a position in the culture of arrival, we inquire about the conditions of production and circulation of two of the current translations of the opuscule "Images" (Eikónes) by Lucian of Samosata, written around the 2nd century A.D. in an artificial attic greek, typical of the atticist movement of the Second Sophistic. In this sense, between the articulation of philological perspective, the traductology of Antoine Berman and the Descriptive Studies of Translation, we observe critically the way in which this text has been interpreted. We analyse a passage in which the multiple decisions of translation shows different conceptions of Lucianic writing and the task of translation. It is observed that the operations dodge the satirical and metapoetic dimension of the text and privilege an encomiastic reading. The advances exposed here are the initial stage in the production of an own translation that retrieves those marks that have been nuanced in the peninsular Spanish versions. The work is part of a broader inquiry about the processes of importation of classical texts between Spain and Argentina and how they delimit and safeguard their possible ways of reading and teaching.

Keywords: Eikones; traductology; Second Sophistic; Lucian of Samosat; ekphrasis; metapoetic.

Los clásicos admiten, inclusive como valor, la ficción de su intemporalidad. Pero las traducciones de los clásicos admiten a su vez la posibilidad de tensionar esa ficción y poner en entredicho ese valor: no solo su emergencia coyuntural puede atravesarlas, ya desde el registro de la lengua a la que se traduce; también puede moldearlas un territorio particular

"Dedicatoria" en Catulito, Sergio Raimondi (2017)

\section{INTRODUCCIÓN}

Eikónes, título que traducimos como "Imágenes", fue escrito hacia el 163 d.C. por Luciano de Samosata durante uno de sus viajes a Antioquía (CISTARO, 2009), en el que coincidió con el emperador Lucio Vero y su concubina Pantea. Este texto, que constituye uno de los escritos breves de su corpus, es un diálogo en el que dos intelectuales (pepaideuménoi) producen conjuntamente un retrato de dicha cortesana. Así, en tanto aparece una figura vinculada al poder imperial (BILLAULT, 2010) se integra en la serie de textos cuyas interpretaciones abren la disputa respecto de la posición política del samosatense. En las traducciones y en numerosos textos críticos se ha sostenido la interpretación de este opúsculo como un encomio (encómion). Sin embargo, tal como ha señalado la crítica más reciente, la 
configuración paródica y satírica del texto pone en tensión su pertenencia genérica. Es así que en "Imágenes" (Eikónes) la polisemia de la escritura luciánica configura una ambivalencia interpretativa entre el encomio, la parodia y la sátira que complejiza el ejercicio de su traducción.

En las dos versiones vigentes al español peninsular - una de Federico Baráibar y Zumárraga publicada en 1889 para la editorial Librería de la Viuda de Hernando y Cía. y la otra de José Navarro González, de 1982, para Gredos-se evidencia el modo en que las traducciones optan por una interpretación encomiástica, obturando estos otros sentidos que el texto griego habilita. De esta manera, buscamos complejizar la lectura de los aspectos centrados en el vínculo de Luciano con el poder imperial produciendo un análisis que nos permita sumar otras discusiones respecto de su escritura y de sus posibilidades y poéticas de traducción.

En el presente trabajo analizaremos dos puntos problemáticos del texto para dar cuenta de las decisiones de traducción y de las condiciones en que se producen y circulan. Por lo tanto, no se trata de identificar estrategias aisladamente y cotejar supuestos desvíos en relación a un original, sino de indagar los motivos por los cuales se privilegian ciertas lecturas por sobre otras y el modo en que intervienen las representaciones hegemónicas de los textos clásicos, de la lengua griega y de la misma tarea de traducción. Es por ello que partimos del análisis de las versiones vigentes del texto como instancia preliminar de la realización de una traducción propia a la variedad del español rioplatense, en pos de configurar una posición respecto de la tradición y de la lengua que nos permita reabrir el acceso (BERMAN, 1999) a la dimensión satírico-humorística y metapoética que el opúsculo configura. De este modo, el presente trabajo se inscribe en el marco de una investigación más amplia que tiene como objetivo central la producción de una traducción crítica de Imágenes ${ }^{2}$ que dialogue con las interpretaciones de los textos luciánicos que se han producido en América Latina.

Jacyntho Lins Brandão (2001) señala que, a pesar de la fuerte influencia que Luciano ha tenido en la literatura occidental (desde Erasmo y Rabelais, Dostoievski y Flaubert, hasta Machado de Assis y Borges en el campo latinoamericano), los

2. En la etapa inicial de la tarea de traducción hemos realizado, en primer lugar, un trabajo analítico e interpretativo del texto en griego y, por otro, en el cotejo de traducciones. A la espera de la edición a cargo de Francesca Mestre, Pilar Gómez y su equipo, que será publicada a la brevedad por la editorial Alma Mater (Barcelona), hemos partido de la edición de MacLeod de 1972. Esta edición está fundada principalmente sobre la tradición $\gamma$ y presenta un amplio y erudito aparato crítico. Se basa en el total de19 manuscritos detallados al comienzo, y otros códices distintos (señalados bajo las siglas rec. o recc.). Actualmente nos encontramos en la etapa de revisión de la primera versión en borrador. Nuestro objetivo final apunta a la publicación de una edición de la traducción destinada principalmente al ámbito educativo de nivel secundario, terciario y universitario. 
trabajos críticos sobre el conjunto de su obra han sido escasos en relación con su importancia documental y, principalmente, literaria. En la primera mitad del siglo XX comenzaron a rebatirse ciertas lecturas ${ }^{3}$ ampliamente difundidas de los textos de Luciano -así como de otros autores de época imperial- que ponían en cuestión su valor al calificarlos como mera imitación o pastiche. Y, tal como precisa el crítico brasileño, desde los estudios de McCarthy (1934) y Bompaire (1958), se ha observado que la mímesis en la escritura luciánica constituye una operación crítica y creativa que tensiona las interpretaciones hegemónicas del canon griego. Se considera entonces que, desde una posición marginal ${ }^{4}$, Luciano no produce una imitación carente de sentido propio sino una lectura dislocada sobre el patrimonio cultural de Grecia. Al decir de Brandão (2001, p. 12), esto lo caracteriza como un autor post-clásico, y es en este sentido que la misma constitución paradojal de su escritura ha producido interpretaciones y lecturas disímiles por parte de la crítica, cuyas disputas aún no han sido resueltas ${ }^{5}$.

En cuanto a los estudios clásicos desarrollados más recientemente en América Latina, señalamos dos lecturas relevantes dentro de nuestra investigación: por un lado, el recorrido que Brandão desarrolla en A poética do Hipocentauro, donde interroga la obra de Luciano a partir de la hipótesis de que el lógos luciánico se constituye como un otro de los discursos consagrados, serios y verdaderos, adoptando así un estatuto de lógos ficcional (BRANDÃO, 2001, p. 27). Por otro, y en diálogo con este planteo, la lectura de María del Carmen Cabrero sobre Narrativas verdaderas, donde sostiene que el juego luciánico configura una "nueva ficcionalidad cuya función social es la de ser expresión literaria de un pensamiento crítico sobre la cultura" (2006, p. 274). Y en este sentido, sugiere que la ficción luciánica habilita la construcción de un espacio utópico que nos sirve como punto de encuentro entre el contexto

3. Parte de las relecturas que revisaron críticamente las interpretaciones dominantes del corpus Lucianeum se ha desarrollado desde los nuevos aportes de la crítica italiana (A. Camerotto, M. Cistaro), francesa (M. J. Bompaire) y española (J. Alsina, F. Mestre, P. Gómez) y, tal como señala María del Carmen Cabrero (2006, p. 6), la "reflexión de la Europa del sur, la que a veces no termina de afirmar su pertenencia al centro o a la periferia" ha resultado particularmente potente para las nuevas interpretaciones de Luciano.

4. Esa marginalidad ya se percibe desde el silencio de Filóstrato (siglo III) en su Biografía de los sofistas, donde escribe ampliamente sobre la Segunda Sofística sin nombrar a Luciano. Esto da cuenta de que su posición periférica con respecto al canon atraviesa su obra ya desde la Antigüedad.

5. Esta polémica en el campo de la crítica -desde Bernays (1879) y Croiset (1882) hasta los estudios de Jones (1986), Branham (1989) y posteriormente Brandão (2001)- en torno a ciertas cuestiones del corpus Lucianeum (como su posición ante el Imperio, su postura frente a la religión y la consciencia sobre su propia escritura) ha sido denominada por Reardon (1971, p. 160) como "cuestión luciánica". Esta noción da cuenta del modo en que el carácter constitutivamente paradojal de la obra del samosatense desbarata la fijación de un único sentido y habilita múltiples interpretaciones, incluso contradictorias. 
de Luciano de la Segunda Sofística en el siglo II y nuestra posición como lectores latinoamericanos de comienzos del siglo $\mathrm{XXI}^{6}$. Ambos críticos coinciden en que la ficción como dimensión característica de la poética luciánica se constituye como un discurso de alteridad ${ }^{7}$, una escritura que busca instituir un espacio dialógico en el que convivan contradictoriamente la tradición y la diferencia.

Estas líneas -que buscan profundizar puntos problemáticos de la obra de Luciano aún no del todo explorados, como lo son la dimensión ficcional y metapoética de su escritura- nos llaman la atención sobre aquellos aspectos que también quedan por abordar en las traducciones. Tal como plantea Even-Zohar, los criterios de selección para traducir una obra están marcados por la situación dominante en el polisistema local. Esto es: "los textos son elegidos según su compatibilidad con las nuevas tendencias y con el papel supuestamente innovador que pueden asumir dentro de la literatura receptora" (1990, p. 225). Así, en lo que refiere al ámbito iberoamericano, tanto las lecturas producidas de Luciano desde nuestras coordenadas como las traducciones actualmente desarrolladas en España ${ }^{8}$, dan cuenta de lo que aún la escritura luciánica tiene para decirnos, al tiempo que interpelan nuestras formas de leer y traducir el canon clásico griego. Es así que el espacio latinoamericano desde el cual este entramado teórico-crítico produce otros modos de interpretar el lógos luciánico nos sirve como punto de partida para pensar, entonces, otros modos de traducirlo desde este lado del Atlántico. Precisamente porque -al igual que María del Carmen Cabrero (2006, p. 4) - lo que atraviesa

6. En este sentido, al concluir su recorrido, Cabrero se pregunta: “¿Por qué aventuramos la idea de que Luciano pueda, eventualmente, ser mejor comprendido por nosotros los ignotos sudamericanos que por los investigadores de los países centrales? Para empezar, porque así sucedió en el pasado: América surgió a la historia de Occidente como proyección utópica de su querer ser, y la función utópica saltó por encima de las cercas de lo literario para rehacer lo nuevo de lo viejo" (2006, p. 275).

7. En este sentido, tanto Brandão (2001) como Cabrero (2006) -cuya perspectiva está atravesada en ambos casos por el concepto bajtiniano de "plurilingüismo"- de doble extranjería: Luciano era de Samosata, una región helenizada de la Mesopotamia que -hacia comienzos del siglo II- que desde el 72 servía de base a una legión romana. Así, el "estar no estrangeiro" al que refiere Brandão (2001, p. 11) se configura desde el punto en que no era griego ni romano. En Dos veces acusado y Un crítico falaz o Sobre el término "nefasto" encontramos una referencia concreta a su origen sirio.

8. Las traducciones más actuales de Luciano al español están a cargo del equipo de Francesca Mestre, Pilar Gómez, Montserrat Jufresa, Eulalia Vintró y Manuela García Valdés, que han continuado la producción de una edición crítica bilingüe de la obra completa del samosatense para la Editorial Alma Mater (del Consejo Superior de Investigaciones Científicas de España) iniciada por el catedrático José Alsina en 1962. Esta edición lleva hasta el momento publicados seis volúmenes, que aún no incluyen Imágenes. En cuanto a Argentina, no se han producido todavía traducciones, lo cual da cuenta en parte del lugar marginal de los textos pertenecientes a la Segunda Sofística dentro del sistema de literaturas clásicas traducidas en relación con otros textos del canon grecolatino, como la épica y la tragedia, o los textos filosóficos de Platón y Aristóteles. 
nuestro trabajo es la pregunta por el "desde dónde": desde dónde se escribe, desde dónde se lee, desde dónde se traduce, desde dónde se enseña y se investiga.

\section{FILOLOGÍA Y TRADUCTOLOGÍA: CRUCES METODOLÓGICOS PARA UNA TRADUCCIÓN DE EIKÓNES}

Entendemos que toda traducción es un hecho situado dentro de la cultura que la produce y, por lo tanto, un ejercicio atravesado por múltiples factores históricos, políticos, ideológicos, estéticos y literarios, al mismo tiempo que por una serie de presupuestos sobre lo que la propia práctica implica. En el campo de los estudios clásicos -que aborda escritos en lenguas que ya no se hablan, que integran un corpus existente limitado y cuyas tradiciones manuscritas continúan siendo discutidas (HARDWICK, 2009) - la perspectiva predominante para abordar la lectura de los textos ha sido la filología. En relación con ello, observamos que en su tarea de traducción tiende a postergarse la profundización sobre las problemáticas específicas de esta práctica y, en cambio, se le asignan los criterios del análisis filológico. Así, considerando las traducciones como textos productores de sentido en múltiples dimensiones, proponemos complejizar el abordaje filológico, por un lado, en cruce con la analítica de la traducción y la traductología de Berman, que consiste en "la reflexión de la traducción sobre ella misma a partir de su naturaleza de experiencia" (1999, p. 18) y, por otro, con la perspectiva de los Estudios Descriptivos de la Traducción (TOURY, 1995), atenta a las características situadas de las traducciones, como los contextos sociohistóricos específicos en las que se producen.

\section{EIKÓNES: RETRATOS, IMÁGENES, REFLEJOS, METÁFORAS, ÍCONOS}

Luciano de Samosata es un escritor de origen sirio que posteriormente adquiere la ciudadanía romana, por lo cual su lengua política llega a ser el latín y su lengua materna, según las hipótesis más convincentes, era el arameo. Sin embargo, desarrolló su obra durante un momento del Imperio Romano -hacia el siglo II d.C.en el que se difundió el fenómeno que Filóstrato definió posteriormente en Vidas de los sofistas como Segunda Sofística, caracterizado por la escritura en griego ático y la reapropiación de la paideía griega. Se produjo así el llamado aticismo, la escritura en un lenguaje artificioso que imita (mímesis) tanto la lengua como el estilo de los autores

9. Para una referencia ampliada en torno a los usos y concepciones de las lenguas en Luciano ver el artículo "Luciano y las lenguas" (2012) de Francesca Mestre. 
griegos canónicos, desde Homero y Hesíodo, hasta Platón, Gorgias y Heródoto ${ }^{10}$. El desarrollo de este fenómeno entre las élites intelectuales (pepaideuménoi), ligado al auge de las escuelas en Roma y a una política imperial expansionista que potenciaba el contacto con otras culturas, generó un escenario plurilingüístico ${ }^{11}$, multicultural y libresco, que dio lugar a una fuerte reflexión sobre el uso de la lengua, así como de la producción y circulación del conocimiento. En este contexto, el samosatense adoptó una posición intelectual de extranjería (BRANDÃO, 2001) y produjo una obra atravesada por una marcada conciencia metalingüística y metapoética. Sobre la base de una configuración paródica y satírica ${ }^{12}$, Luciano construye una poética a partir del procedimiento de la mîxis (fusión, mezcla) de elementos dispares de la tradición canónica griega, como el diálogo aristofánico y el filosófico platónico ${ }^{13}$, produciendo una innovación genérica. A partir de ese movimiento desacralizador, crea una obra nueva que provoca un efecto de extrañamiento (thaûma) y desnaturaliza las formas en que las ideas mismas de saber, verdad y conocimiento son legitimadas.

En esta complejidad escrituraria se inscribe "Imágenes" (Eikónes), cuya disputa respecto de sus interpretaciones se abre desde el punto en que no adopta la configuración convencional para el encomio, que es la prosa monológica ${ }^{14}$, sino que se constituye como un diálogo entre Polístrato y Licino -dos personajes recurrentes dentro de la obra de Luciano- que surge a partir de un encuentro espontáneo en la calle, al modo platónico. Licino aparece shockeado por la visión (ópsis) de

10. Existen diferentes perspectivas en torno al fenómeno lingüístico y cultural del aticismo. Seguimos aquí principalmente los diferentes recorridos propuestos por Francesca Mestre, condensados en el texto de 2012 citado en la nota anterior, donde señala diferentes posturas frente al tratamiento de la lengua en Luciano. Para un recorrido histórico de la configuración del aticismo ver el desarrollo de Adrados en su Historia de la lengua griega (1999).

11. Para Bajtín (1975) el plurilingüismo social, donde resuenan los ecos dialógicos, ha sido central como fuerza creadora en el surgimiento de la prosa novelesca de época imperial, en la medida en que fecunda las divergencias y contradicciones individuales que "penetran en los estratos profundos de la [palabra], dialogizan el lenguaje mismo, la concepción lingüística del mundo (la forma interna de la palabra)".

12. Por un lado, entendemos la parodia como la operación intertextual que está en la base de la configuración de la escritura de Luciano (Camerotto, 1998), a través de la cual se reapropia de los textos de la paidéa griega construyendo una relectura y reescritura crítica. Por otro lado, nos referimos a la sátira como uno de los estilos que absorbe, proveniente de la sátira menipea: género en prosa que desarrolló el cínico Menipo de Gádara hacia el siglo IV a.C. Estos textos constituyen una crítica de la realidad y del sistema de valores y creencias de la sociedad contemporánea, como la riqueza, el poder, la fama, la religión y las supersticiones. Esto es, implica un discurso que pone en entredicho todos los valores de la paideía (Camerotto, 2014, p. 16)

13. Para un desarrollo ampliado de la mixis ver Camerotto (1998). Dos de los textos donde Luciano presenta e interroga particularmente este procedimiento compositivo son Doble acusación y A quien dijo: "eres un Prometeo en tus discursos".

14. No nos ocuparemos aquí de las divergencias genéricas de Eikónes en relación con el encomio, lo cual se encuentra desarrollado minuciosamente en Cistaro (2009). 
una mujer cuya extrema belleza es imposible de explicar y Polístrato insiste a su interlocutor para que por medio de palabras (lógos) ponga delante de sus ojos (bypódeixon) aquella figura (ềdos) que vio. Licino argumenta la imposibilidad de hacer aparecer con palabras aquella imagen ${ }^{15}$, instalando desde el inicio el problema de su propia (in)capacidad como artista (tekhnites), y de lo que la lengua misma puede (dýnamis) o no decir y hacer ver. De esta forma, Licino recurre a la invocación de los antiguos (tôn palaiôn tinas ekeínon tekbnitôn) para que compongan la imagen que él mismo vio, pero no puede reproducir. En la mitad del diálogo, Polístrato reconoce que se trata de Pantea a partir de la descripción que Licino ha hecho de los aspectos de su cuerpo (sôma) y continúa la configuración del retrato con los aspectos de su alma (psykbé). Hacia el final de la conversación proyectan plasmar en un libro la imagen de palabras que han concluido, donde resultará más duradera que el mármol, la pintura o el bronce.

El retrato de Pantea se construye entonces como un mosaico de fragmentos de piezas pictóricas de los escultores, pintores y escritores canónicos de la paideía griega, ensamblados a través del lógos: Praxíteles, Alcámenes, Fidias y Cálamis para componer la eikón del cuerpo (sôma); Homero, Píndaro, Safo, Platón, Jenofonte, para componer la eikón del alma (psykbé). A partir de esa intertextualidad se configura un discurso extremadamente artificioso por la acumulación excesiva de écfrasis ${ }^{16}$, y ese carácter hiperbólico problematiza la función encomiástica del texto (CHIALVA, 2014). De este modo, Imágenes no podría ser leído simplemente como un encomio o una sátira sino como el teatro mismo de la escritura luciánica, ya que en el ensamblaje de textos a partir del cual se configura, exhibe el funcionamiento del procedimiento paródico que está en la base de la creación de su escritura: la mezcla (mîxis) de géneros, de prosa y verso, de autores, de palabras, de imágenes, de discursos, de

15. "Polístrato- Es obvio que te quedaste hecho una piedra (...) Pero no importa, ahora, como sea, haceme ver esa figura con palabras, así al menos podría llegar a conocerla.

Licino- ¿Ves lo que me estás pidiendo? No pueden las palabras, y menos todavía las mías, hacer aparecer una imagen tan impresionante. Para eso, y aún con mucho trabajo, Apeles o Zeuxis o Parrasios parecieron capaces, o quizás algún Fidias o Alcámenes. Pero yo, voy a profanar el original con la incapacidad de mi arte.

P-Pero igual Licino, decime cqué cosa es esa visión? Porque no es arriesgado el atrevimiento, si exhibís esa imagen delante de un amigo, aunque sea un esbozo." (Im.,3. la traducción es nuestra)

16. Según la definición que presenta Aftonio (siglo IV d.C.) en los Progymnásmata, manuales de retórica, la écfrasis es "una composición que expone en detalle y presenta ante los ojos de manera manifiesta el objeto mostrado" (Progym. 12,36). Esta figura, que ocupó un lugar central dentro de la cultura visual de la Segunda Sofística, no solo consistió en representaciones detalladas de objetos artísticos, esculturas y pinturas (eikónes), tal como la del escudo de Aquiles en Ilíada (18), sino también de personajes y hechos, de circunstancias y lugares, animales y árboles. 
eikónes (CAMEROTTO, 1998, p. 75). Y es allí donde se desafía la propia capacidad (dýnamis) del lógos para decir y hacer ver aquello que está enunciando ${ }^{17}$.

Desde el título Eikónes -que es al mismo tiempo retratos, imágenes, reflejos, metáforas, íconos- el texto condensa y explota formalmente cada una de las acepciones, haciendo del retrato de Pantea un retrato de la propia escritura. Así, instala ambivalencias que desdibujan sus características genéricas y plantean un problema central en cuanto a las decisiones de traducción. La versión del título será entonces un primer punto de partida para identificar ciertas divergencias en cuanto a la interpretación del texto.

En el Dictionnaire des intraduisibles (2004) dirigido por Bárbara Cassin, el término eikón aparece junto a tó eikós y eídolon, como parte de la familia semántica de *weikô (parecer), cuyo sentido primario refiere a la similitud de un objeto con otro. Asimismo, encuentra una vinculación conceptual con phántasma y émphasis, derivados del verbo phainesthai (hacer ver, aparecer). Todos estos lexemas que se inscriben dentro de un campo semántico relativo a la imagen, a la percepción visual y a la construcción de imágenes mentales, aparecen condensados en el significante eikón y complejizan de ese modo su traducción. Porque al mismo tiempo este término puede referir a estatua y retrato, pero también a reflejo, como la imagen producida en un espejo o a una imagen mental. Asimismo, puede referir a la figura retórica de la comparación o traducirse como figura o forma. Y dentro de las nociones de representación que abre, según explica Cassin (2014, p. 245), evoca una proximidad con el objeto que representa, de donde adquiere su etimología el término ícono.

Es así que eikón abre una pluralidad de significados que pueden referir tanto a la percepción visual de objetos físicos como a las imágenes en tanto producto de la memoria o de la imaginación. Desde la épica homérica y la tragedia de Eurípides, hasta Platón y Aristóteles, el término ha ido absorbiendo múltiples voces que se impregnaron también de las referencias y usos retóricos que circulaban en la época imperial. Y de este modo, encontramos que Luciano pone a funcionar simultáneamente dentro del texto todos los sentidos del término.

Esta lectura del texto encuentra un diálogo con las interpretaciones críticas que desde Camerotto (1998) y más recientemente (BRANDÃO, 2001; CHIALVA, 2014; CISTARO, 2009) se han producido en clave metapoética, pero no encuentra su correlato en las traducciones, que focalizan en otros aspectos de la escritura luciánica. Las dos traducciones de Eikónes al español peninsular -una de Federico

17. Esta lectura del texto se encuentra argumentada en detalle en nuestro trabajo "Hacer ver la lengua con palabras: problemas teóricos y metodológicos en torno a la traducción de la escritura luciánica", presentado en la "II Jornada de avances en investigaciones teórico-literarias para estudiantes avanzados de grado y graduados recientes", desarrolladas en la UNL el 14 de septiembre del 2016. 
Baráibar y Zumárraga publicada en 1889 y la otra de José Navarro González de 1982- optan por traducir "Los retratos". Y ya desde esta interpretación inicial se desprende una lectura que de algún modo obtura los ecos filosóficos, retóricos y pictóricos que resuenan en el título y que operan a lo largo del texto. Consideramos que un término que podría mantener la polivalencia del título en griego sea "imágenes", palabra múltiple y ambigua, que habilita en la traducción otros juegos significantes.

\section{SER EL CUERPO DEL TEXTO: LA EIKÓN DE PANTEA COMO FIGURACIÓN METAPOÉTICA}

Luego del desarrollo de la escena inicial, en la que Licino expone a Polístrato los principios estéticos y compositivos que utilizará para reconstruir la imagen de Pantea, comienza -en el parágrafo 6, donde se inicia la construcción del cuerpo (sôma) mediante el ensamble de diferentes piezas escultóricas- la configuración de la imagen (eikón) como tal, el pastiche ecfrástico de imágenes (eikónes):

Licino -Y ahora podés ver la imagen que resultará, componiéndola así: de la que viene de $\mathrm{Cnnido}^{18}$ sólo seleccionando la cabeza, porque nada del resto del cuerpo, al estar desnudo, hará falta. Lo que rodea el cabello y la frente, y el trazo definido de las cejas, quedarán como lo hizo Praxíteles. Y de los ojos la sensualidad, junto con el brillo y el encanto: también esto será cuidado según el parecer de Praxíteles. Y además las mejillas, tanto como el aspecto de frente se lo tomará de Alcámenes y de la del jardín ${ }^{19}$. Y también el extremo de las manos y la proporción de las muñecas y la delicadeza de los dedos terminados en punta, será todo eso tal como la de los jardines. Y a ella el contorno de todo el rostro y la suavidad de las mejillas, y la simétrica nariz, se lo ofrecerá la Lemnia, y Fidias. Y así, la articulación misma de la boca y el cuello se elegirá según la Amazonas. Y además, la Sosandra y Cálamis la dispondrán a ella misma con cuidado, y la sonrisa será también seductora y sutil como es aquella. Y también la liviandad y la modestia del manto como el de la Sosandra, excepto que ésta tendrá la cabeza descubierta. Pero de la medida de su edad, cuánto llegaría a tener, tal como aquella de Cnidos

18. Afrodita de Cnido, esculpida por Praxíteles en Atenas aproximadamente hacia el 360 a.C. La ciudad de Cnido la adquiere luego de que fuera rechazada por la ciudad de Cos a causa de la sensualidad de la representación. Plinio el Viejo relata un tópico que será recurrente en la literatura: un joven que se enamora de la estatua. De ahí que de esta representación considerada impúdica Licino decida tomar solo la cabeza porque no necesita del resto del cuerpo en tanto está desnudo.

19. De las numerosas esculturas de Afrodita conocidas en la antigüedad, ésta es la Afrodita de los jardines (en képois). Se trata de un lugar en las afueras de Atenas, cerca del Iliso, donde según la Descripción de Grecia $(1,19,2)$ de Pausanias (siglo II d.C.) había un templo dedicado a esta diosa con una famosa estatua esculpida por Alcámenes. Esta obra también es mencionada en el libro XXXVI de la Historia Natural de Plinio el Viejo (siglo I d.C). 
precisamente. Y así también esto será medido según Praxíteles. ¿Qué te parece, Polístrato? ¿Resultará hermosa la imagen? (Im, 6. La traducción es nuestra) ${ }^{20}$

Tanto en la selección léxica como en la disposición sintáctica se pone en escena el funcionamiento del texto a través de una codificación que abre dos dimensiones: una visual y otra teórica. En primer lugar, observamos que el pasaje presenta una estructura circular en torno al verbo gígnomai (resultar, devenir), que construye al mismo tiempo un modo de configuración del texto y un modo de lectura.

Una vez que Licino ya se aseguró de que su interlocutor ha actualizado en su mente la serie de imágenes a las que referirá posteriormente, le indica que podrá ver (borân) la imagen (tén eikóna) que resulte (gignoméne) a partir del trabajo de composición (synarmózon) que ensamblará las partes: "Y ahora podés ver la imagen que resultará, componiéndola así" (Im. 6, la traducción es nuestra). Con este primer enunciado, dirige la interpretación de los elementos que construirá a continuación, estableciendo por tanto una necesaria colaboración por parte de su interlocutor para el trabajo de composición de la eikón.

Por otra parte, presentada esta clave de lectura, comienza a introducir cada una de las referencias con las que configura la imagen del cuerpo a través de términos que refieren tanto a una figura corporal como a una operación poética-retórica. Así, ingresan al ensamble de la la eikón con una doble función: especifican el recorte de las figuras corporales del texto parodiado y a la vez se proyectan sobre él en términos metapoéticos: "el trazo definido (tó eúgrammon) de las cejas", "la proporción (tó eúrytbmon) de las muñecas", "la articulación (barmogén) de la boca", "el contorno (perigraphén) de todo el rostro".

Hacia el final de este pasaje, cuando ya se han presentado todos los fragmentos específicos de cada una de las obras, Licino enuncia una pregunta en

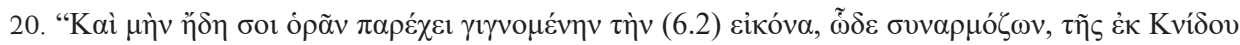

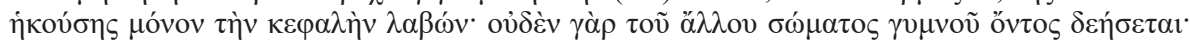

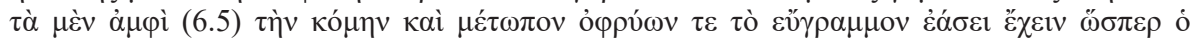

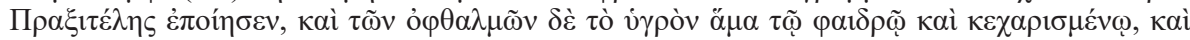

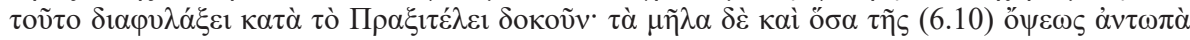

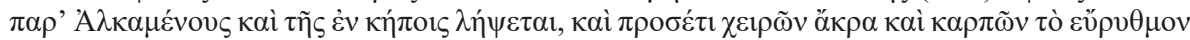

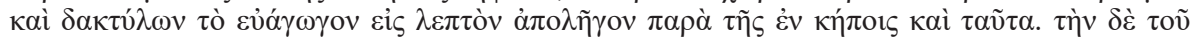

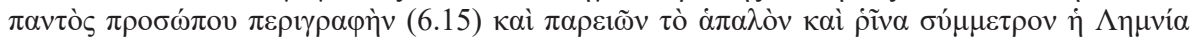

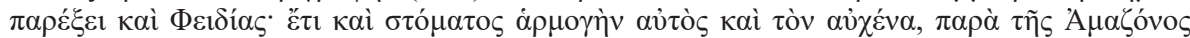

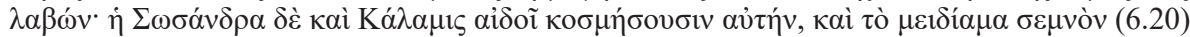

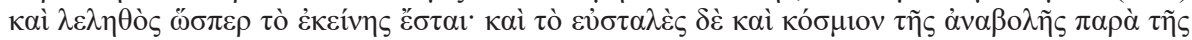

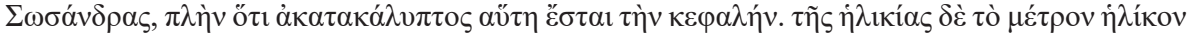

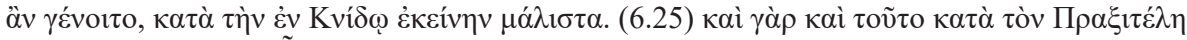

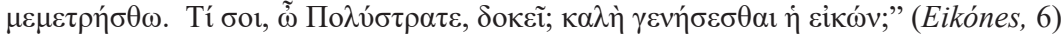


la que reaparece -ahora en forma de infinitivo pasivo- el verbo gígnomai (resultar, devenir): ¿Resultará (genésesthai) hermosa la imagen? Al retomar este verbo que se introdujo al comienzo, podemos pensar que se configura una estructura circular y se resignifica, en la medida en que pone en evidencia el proceso poético del texto. El texto se presenta así, en el inicio y hacia el final de este fragmento, como la eikón producto de una tarea de ensamblaje que será ejecutada a través de un proceso de selección (lambáno) de cada uno de los elementos que lo integren.

Ambas traducciones al español pasan por alto estas marcas, que constituyen una reflexión teórica sobre la propia hechura (poíesis) del texto: en la traducción de Baraibar y Zumárraga (1892) de la primera frase ("Vas a ver esa imagen, compuesta por mí") se elimina el participio de gígnomai, y lo que se borra allí precisamente es la idea de imagen en construcción. Asimismo, en la traducción de Navarro González (1992) sí se incorpora el participio ("Ya puedes ver la imagen resultante, componiéndola de la siguiente manera"), pero no se mantiene el mismo significante en la última oración, en tanto primero traduce el gígnomai como "resultar" y luego como "ser", rompiendo la estructura circular del fragmento.

Al mismo tiempo, Baraibar y Zumárraga recupera los términos que hemos indicado en una sola expresión: "Los cabellos, la frente y las cejas, que parecen obra de pincel". Señala así la cualidad artificiosa de cada uno de esos elementos, pero vuelve a matizar la precisión de la operación de la escritura luciánica. La elección del término "comisura" de los labios de igual forma desplaza la posibilidad de recuperar una referencia gramatical como la de harmogén (articulación).

El mismo movimiento se produce con los verbos allí presentes: en la traducción del verbo kosméo (disponer, ordenar) por "embellecer" y "adornar" sólo se recupera el sentido relacionado a la belleza, borrando la operación de disposición y orden que esa noción presupone y que refiere por lo tanto a un modo de hacer (poíesis) con el lógos. Lo mismo sucede en ambas traducciones con el verbo lambáno ("seleccionar"), que aparece como "tomar" o directamente "ser", matizando la insistencia del texto en enunciar siempre el proceso de selección en tercera persona: no es Licino quien selecciona, sino el lógos (cfr. Im. 5).

Estos términos que hemos señalado adoptan una significación particular en tanto aparecen en otros pasajes del corpus Lucianeum en los que se profundiza la dimensión metapoética. Por tanto, abordar una lectura intertextual en relación a otros textos de Luciano donde se construyen figuraciones de la propia escritura 
(como lo son Zeuxis, En favor de Imágenes, Dionisio o Hércules) ${ }^{21}$, nos permitiría recuperar en la traducción las redes significantes subyacentes (BERMAN, 1999, p. 65). En Imágenes, esa red conceptual se configura mediante una estructura polisindética que señala en su propia estructura sintáctica la yuxtaposición de elementos por acumulación. Se produce así una hipercodificación del cuerpo de Pantea mediante esa red, pero también a través de las múltiples referencias intertextuales, que ponen en escena la configuración paródica de la escritura luciánica. Es así que Pantea se presenta -en línea con la imagen del hipocentauro de Zeuxis (BRANDÃO,2004)como una figuración estética y teórica de la propia escritura, ante la que no se resiste la dicotomía forma/contenido.

Esta operación supone una marca constitutiva de la escritura de la Segunda Sofística, en la que la tékbne ya no es, al modo aristotélico, una mímesis -en términos de imitación creativa- de la naturaleza, sino del discurso y de la cultura. Y es por ello que su configuración es estructuralmente paródica, en tanto se constituye a través de la reapropiación de una multiplicidad de textos de la cultura grecolatina.

Vemos entonces que la traducción de la escritura luciánica se complejiza en tanto se producen múltiples niveles de traducción: el mismo uso de la lengua ática -artificiosa y anacrónica- por parte de ciudadanos romanos, pero también el pasaje del código visual al lingüístico y la red de referencias paródicas que se actualizan en la lectura.

Tanto la versión de Baraibar y Zumárraga como la de Navarro González se inscriben en proyectos editoriales que han presentado colecciones completas de los textos clásicos - enmarcadas en las llamadas series "Biblioteca clásica" produciendo traducciones desde una serie de criterios configurados principalmente a partir de una perspectiva filológica y humanista. Hasta el año 1882 en España solo se había traducido un número reducido de sus textos, por lo cual la edición de la Librería de Hernando y Cía. es la primera versión total en España, que incluye por primera vez "Los retratos", siendo así la primera traducción (BERMAN, 1999, p. 115), mientras que la de Gredos publicada en 1988 constituye una re-traducción $n^{22}$. Las dos traducciones peninsulares que hemos analizado se inscriben en tradiciones filológicas que se distancian de las lecturas que señalamos. Y el peso de la tradición

21. En la obra de Luciano los elementos de la tradición literaria se reconfiguran en una paradoja formal y semántica a partir de la hibridación (mîxis) de términos inconciliables. Esta operación literaria da por resultado una creación nueva que se caracteriza por los efectos de extrañamiento provocados por su carácter paradójico. En la serie que mencionamos se construyen figuraciones de la propia poíesis a través de las que se indaga en los efectos sobre sus espectadores: un ejército de elefantes en Dionisio; en Zeuxis el cuadro del hipocentauro, animal híbrido y desproporcionado; la imagen extranjerizante del Heracles Ogmio por origen celta; la obra como "un camello entre los egipcios".

22. Ver n. 8. 
-principalmente donde los estudios clásicos están más fuertemente establecidos en el ámbito tanto académico como editorial- opera en ocasiones con más fuerza que la propia capacidad de decisión de los traductores. Es por esto que resulta necesario problematizar la idea de "responsabilidad" respecto de las decisiones de traducción, en tanto son múltiples los agentes que intervienen en ellas: desde las restricciones impuestas por las políticas editoriales, las tradiciones escolares y académicas que modelan la propia práctica de los traductores y el mismo campo cultural en el que se inscriben. De este modo, desde una concepción decimonónica de la filología, el criterio principal es el establecimiento y fijación de los textos en pos de una supuesta restitución de su sentido (BERMAN, 1999, p. 133). Así, se delimita y valora el "propósito" de la traducción desde un entramado de supuestos en el que priman los conceptos de "corrección" y "exactitud" de un "texto original". Esto es: los objetivos de la filología se confunden con los de la traducción. Y precisamente donde se privilegia la traducción del "sentido" por sobre la de los significantes termina por anularse aquello que constituye y caracteriza la escritura luciánica: el trabajo de la letra, la irreductible pluralidad de significantes.

\section{CONCLUSIONES}

A través de una configuración metapoética y de la búsqueda de un efecto de extrañamiento, Luciano ha producido una fuerte importación cultural de la paidéa griega al escenario romano imperial, mediante un discurso crítico y desacralizador. Hemos analizado un pasaje de Eikónes -y el título mismo- en el que observamos cómo se produce una reapropiación a través de un procedimiento paródico y metapoético, en el que se pone de manifiesto el funcionamiento de la propia escritura. Sin embargo, esta configuración característica de su escritura -que ha sido ampliamente indagada en la crítica más reciente, desde Bompaire (1958) en adelante- se encuentra de algún modo soslayada en las traducciones vigentes. Si la escritura de Luciano se presenta como un mosaico de lenguas, de textos, de géneros que, a través del procedimiento compositivo de la mîxis, produce un efecto de extrañamiento sobre todo lo que ingresa a ella, cabe la pregunta por la traducción de esa multiplicidad, precisamente porque es en esa configuración donde se juegan las marcas constitutivas de la graphé (escritura, dibujo) luciánica. De esta forma, buscamos una posición que -aun considerando la imposibilidad de traducir ciertos juegos significantes y ambigüedades, los ecos y referencias intertextuales- apueste por recuperar la dimensión estética y literaria que se juega en el texto. Así, desde una perspectiva que nos permita identificar los procesos de significación que se activan 
en toda traducción y que condicionan la lectura de los textos, nos preguntamos por la posibilidad de realizar versiones que dejen ver la poética de su graphé y recreen el extrañamiento de esos textos sobre el canon y la tradición. Esto es, desnaturalizar los procesos de traducción que localizan los textos dentro del campo de la cultura de llegada para poder tomar decisiones respecto del borizonte (BERMAN, 1999, p. 138) en que queremos anclar nuestra traducción y nuestro modo de leer el corpus de textos clásicos. Porque los elementos que intervienen en cada reescritura configuran una imagen que habla más de los mecanismos políticos e ideológicos de regulación de los textos que de los textos mismos.

Nos proponemos partir de los abordajes filológicos e intertextuales que nos permiten ingresar a la lectura de esa lengua escrita, para intentar reabrir desde allí algo de los sentidos y el trabajo con la letra que se juega en los textos. De este modo, al volver sobre las concepciones que el mismo texto exhibe podemos encontrar una idea de traducción más ligada al propio texto que a las tradiciones que nos obturan su acceso. Es entonces que la posición periférica en relación al campo internacional de los estudios clásicos desde la que buscamos producir una traducción al rioplatense -lengua también marginal- de un autor que en Argentina no ha sido importado ${ }^{23}$ en una posición central dentro del canon clásico grecolatino, puede constituir una oportunidad para reabrir aquello que está resguardado. Quizás nuestra posición de distanciamiento con respecto a las tradiciones hegemónicas que han protegido las interpretaciones en torno a "los clásicos" sea también la que nos permita producir versiones que recuperen aquellas dimensiones anestesiadas en las traducciones vigentes.

\section{REFERENCIAS BIBLIOGRÁFICAS}

ADRADOS, F. R. (1999). Historia de la lengua griega. De los orígenes a muestros días. Madrid: Editorial Gredos.

BAJTíN, M. (1975). Teoría y estética de la novela. Traducción de Helena S. Kriukova y Vicente Cazcarra. Madrid: Taurus, 1989.

23. Con la noción de importación nos referimos a lo que Romano Sued (2009, p. 21-22) define como los "modos de apropiación de modelos, formas retóricas, ideas, superando el sentido básico de la permutación lingüística de vocablos". Esta consideración nos permite problematizar las condiciones en que toda traducción se produce y circula. Esto es, poner de relieve el "conjunto de prácticas discursivas, políticas editoriales y mecanismos institucionales de consagración que acompañan a la traducción como otros tantos dispositivos capaces de actuar sobre la legibilidad del texto extranjero" (WILLSON, 2007, p. 20). 
BERMAN, A. (1999). La traducción y la letra o el albergue de lo extranjero. Traducción de Ignacio Rodríguez. Buenos Aires: Dedalus, 2014.

BILLAULT, A. (2010). Lucien, Lucius Verus et Marc Aurèle. In: Mestre, F. y Gómez, P. (Eds.) Lucian of Samosata. Greek writer and roman citizen. Barcelona: Universitat de Barcelona, 2010, pp. 145- 159.

BRANDÃO, J. L. (2001). A poética do bipocentauro. Literatura, sociedade e discurso ficcional em Luciano de Samósata. Belo Horizonte: Editora UFGM.

CABRERO, M. C. (2006). Elogio de la mentira. Sobre las narrativas verdaderas de Luciano de Samósata. Bahía Blanca: Universidad Nacional del Sur - Ediuns.

CAMEROTTO, A. (1998). Le metamorfosi della parola. Studi sulla parodia in Luciano di Samosata. Roma-Pisa: Istituti Editoriali e Poligrafici Internazionali.

CAMEROTTO, A. (2014). Gli occhi e la lingua della satira. Studi sull'eroe satirico in Luciano di Samosata. Milano-Udine: Mimesis Edizioni.

CASSIN, B (Ed.) (2004). Dictionary of untranslatables: a pbilosopbical lexicon. Traducción de Steven Rendall, Christian Hubert, Jeffrey Mehlman, Nathanael Stein, y Michael Syrotinski. Traducción editada por Emily Apter, Jacques Lezra y Michael Wood. Princeton: Princeton University Press, 2014.

CHIALVA, I. (2014). Elogio, adulación y parodia: desconciertos en torno al encomio Imágenes de Luciano. In Mestre, F., Gómez, P. (Eds.) Three Centuries of Greek Culture under the Roman Empire. Barcelona: Edicions UB, pp. 201-234.

CISTARO, M. (2009). Sotto il velo di Panthea. Imagines e Pro imaginibus di Luciano. Messina: Orion.

EVEN-ZOHAR, I. (1999). La posición de la literatura traducida en el polisistema literario. In Teoría de los Polisistemas. Estudio introductorio, compilación de textos y bibliografía por Montserrat Iglesias Santos. Madrid: Arco, pp. 223-231.

HARDWICK, L. (1998). "Classical Texts" en Mona Baker y Gabriela Saldanha (eds.) Routledge Encyclopedia of Translation Studies ( $2^{\circ}$ ed.) New York: Routledge, 2009, pp. 34-37.

LEFEVERE, A. (1992). Traducción, reescritura y la manipulación del canon literario. Traducción de María Carmen África Vidal y Roman Álvarez. Salamanca: Biblioteca de traducción, 1997. 
LIDDELL H.G., SCOTT R., JONES H.S. (1843). A Greek-English Lexicon (LSJ). Oxford: Oxford University Press „1996.

LUCIAN. Luciani opera. Recognovit brevique anotattione critica instruxit M. D. Macleod. Oxford: Clarendon, 1974 (v.II); 1980 (v. III).

LUCIANO. Obras completas de Luciano, traducidas directamente del griego con argumentos y notas por Federico Baraibar y Zumárraga, Cristobal Vidal y F. Delgado. Madrid: Librería de la Viuda de Hernando y Cía., 1882-1890.

LUCIANO. Obras II. Traducción y notas por José Luis Navarro González. Madrid: Biblioteca Clásica Gredos, 1988, tomo 113.

PABÓN S. DE URBINA, J. (1967). Diccionario bilingüe Manual Griego clásico-español. España: VOX, 2012.

PAUSANIAS. Descripción de Grecia. Libros I-II. Introducción, traducción y notas de Ma. Cruz Guerrero Ingelmo. Madrid: Editorial Gredos, 1994.

ROMANO SUED, S. (2009). "Traducción, nación e identidad cultural en América Latina". Nostromo. Revista crítica latinoamericana, Año 2, No 2, pp.19-27.

TEÓN, HERMÓGENES, AFTONIO. Ejercicios de retórica. Introducción, traducción y notas de Ma. Dolores Reche Martínez. Madrid: Editorial Gredos, 1991.

TOURY, Gideon. (1995). Los estudios descriptivos de la traducción y más allá. Metodología de investigación en estudios de traducción. Trad. de R. Rabadán y R. Merino. Madrid: Cátedra, 2004.

WILLSON, P. (2007). Traductores en el siglo. Punto de Vista, 87, pp.19-25.

Recebido: 10/02/2018

Aceito: 28/02/2018 